\title{
Aktywność - twórczość - emocje. Przestrzenie transformacji i synergii
}

\begin{abstract}
Abstrakt
Przedmiotem artykułu jest namysł nad procesami transformacji zachodzących w złożonej przestrzeni aktywności na styku - doświadczeń, poznania, twórczości i emocji. Punktem wyjścia rozważań jest koncepcja analizy transwersalnej aktywności (Babier 2015, 2016). Opracowanie ukazuje strukturę działań twórczych w celu wykorzystania jej do analizy specyficznego rodzaju zachowań transformatywnych. Proces twórczy można rozpatrywać jako „transformację transformacji” oraz synergii. Proces tworzenia w perspektywie transwersalnej stanowi heurystyczny wymiar poszukiwań.
\end{abstract}

Słowa kluczowe: aktywność, transformacja, proces twórczy, analiza transwersalna, synergia.

\section{Activity - Creativity - Emotions. Spaces of Transformation and Synergy}

\begin{abstract}
The subject of the article is a reflection on the transformation processes taking place in the complex space of activity at the interface - experience, cognition, creativity and emotions. The starting point for the considerations is the concept of the analysis of transversal activity (Babier 2015, 2016). The study shows the structure of creative activities in order to use it to analyse a specific type of transformative behavior. The creative process can be viewed as a "transformation transformation" and synergy. The process of creation in the transversal perspective is the heuristic dimension of the search.
\end{abstract}

Keywords: activity, transformation, creative process, transversal analysis, synergy.

\footnotetext{
* Uniwersytet w Białymstoku.

Artykuł otrzymano: 9.02.2021; akceptacja: 20.04.2021.
} 


\section{Wprowadzenie}

"Człowiek opanowujący przyszłość jest jednocześnie jej twórcą"

(Obuchowski 1985)

Działalnością/aktywnością jest to, co podmiot robi w świecie i to, co się w nim samym dokonuje podczas tej aktywności. Wszystkie nasze aktywności, nawet te, które napotykają na trudności, czy te najbardziej tłumione, pozostawiają ślady w nas samych. Następnie te ślady odzwierciedlają się w kolejnych podejmowanych aktywnościach (Barbier 2015: 66).

Punktem wyjścia rozważań jest koncepcja analizy transwersalnej aktywności - jak ją ujmuje Jean-Marie Barbier - pozwalająca orientować problematykę w kierunku przestrzeni aktywności, ich konfiguracji i transformacji zachodzących w różnych przypadkach/sytuacjach edukacyjnych i społecznych (Babier 2015, 2016b). W świetle tej koncepcji również życie definiuje się jako spiralny splot aktywności (Barbier 2016b; Marynowicz-Hetka 2018). Stanowi proces, w którym i dzięki któremu realizowana jest aktywność jednostki i jej trwanie. Mechanizmy zachodzące $\mathrm{w}$ tym procesie charakteryzuje spiralne powiązanie. Jest to aktywność wielokrotnie złożona, podlegająca permanentnym transformacjom. Działalność/aktywność definiujemy - jak mówi Jean-Marie Barbier - jako zespół p r ocesów transformacji świata fizycznego, mentalnego, społecznego (często i wszystkich trzech razem), w które zaangażowany jest podmiot. W podejściu dynamicznym - w odniesieniu do procesu przekształceń - perspektywą analizy jest uznanie statusu pojęcia emocji, będących jednocześnie motorem aktywności, nadającym rytm działaniom, jak też pośrednikiem między zjawiskami mentalnymi, afektywnymi i poznawczymi (Babier 2015: 68).

Przykładem aktywności złożonej i podlegającej transformacjom jest działanie twórcze. Zachodzi w złożonej przestrzeni: poznania - tworzenia (stwarzania) - emocji. Twórczość jako aktywność prowadzi do pojawienia się osiągnięć stanowiących dalsze zmiany. Twórczość ma naturę antynomiczną i dialektyczną. Charakterystyczną cechą zarówno aktywności, jak i transformacji jest ich złożoność, powiązanie i równoległość występowania. Przy rozpatrywaniu transformacji - czynności w aktywności - promowane jest podejście dynamiczne. Aktywność jest zarówno konstruowaniem, ale także ciągłym/nieprzerwanym rekonstruowaniem.

Przedmiotem podjętych rozważań jest spojrzenie na aktywność twórczą w perspektywie procesów transformacji. Opracowanie zawiera operacjonalizację struktury dynamiki działań twórczych, aby można było je wykorzystać do analizy specyficznego rodzaju zachowań transformatywnych. Proces twórczy można rozpatrywać jako „transformację transformacji” oraz synergii. Z punktu widzenia aktywności ujętej jako „transformacja transformacji” stanowi ona splot aktywności obejmujący wymiar - teraźniejszy, przeszły i przyszły oraz obecne w niej potencja- 
ły. Efekt synergii służy podkreśleniu wzmacniającego wymiaru rezultatów współpracy, współdziałania i współtworzenia. Podobnie jak w podejściu dynamicznym - obecność emocji w procesie twórczym pełni rolę moderatora.

\section{Istota podejścia transwersalnego na tle interdyscyplinarności}

Przesłanką zaistnienia podejścia transwersalnego jest zauważenie niedostatków znanych perspektyw poznania i działania. Interdyscyplinarność ${ }^{1}$ miała być środkiem zaradczym (remedium) na kakofonię języków teoretycznych, a tymczasem jej kryzys przejawia się w zamykaniu we własnych specjalnościach, braku porozumienia i wspólnego języka oraz braku możliwości syntezowania wyników badań, a przeciwstawnie pojawiają się usilne dążenia do zachowania autonomii dyscyplin i subdyscyplin. W efekcie nie udaje się stworzyć pełnego obrazu poznawanego przedmiotu (Dudzikowa 2012: 19). Podejście dyscyplinarne odznacza się tym, że wszystkie czynności badawcze i działaniowe realizują się w oparciu o koncepcję opracowaną wspólnie przez przedstawicieli różnych dyscyplin, w równoprawnym dialogu i permanentnej interakcji, co może wyzwalać synergię epistemologiczną, metodologiczną, metodyczną i praktyczną. Podejście transwersalne natomiast może być ujmowane różnorodnie. Stanowi próbę oglądu rzeczywistości w trzech wymiarach: „Z zewnątrz” dyscypliny, „od wewnątrz” oraz „ponad” - czyli całościowo. Jest ona efektem zarówno utrzymania i wzbogacenia tożsamości dyscyplinarnej, jak i wykorzystywania doświadczeń i zdobyczy interdyscyplinarności w rozumieniu i doskonaleniu praktyki. W rezultacie może dochodzić do krystalizacji ram dyscyplinarnych, tworzenia koncepcji metodologii transdyscyplinarnych i ich stosowania oraz projektowania praktyki uwzględniającego efekty badań wielu współpracujących ze sobą dyscyplin (Marynowicz-Hetka 2008: 57-59).

\section{Koncepcja analizy transwersalnej aktywności}

Perspektywa działania/aktywności - jak ją ujmuje Jean-Marie Barbier - znajduje się w kategorii nowego wyzwania dla badań w naukach o wychowaniu. Przypuszcza się, że w związku ze zmianami ekonomicznymi i społecznymi zarówno edukacja, jak też kształcenie, jako aktywności profesjonalne, podobnie jak inne pola oddziaływania na Innego (zarządzanie, doradztwo, opieka, praca socjalna, komuni-

\footnotetext{
${ }^{1} \mathrm{~W}$ kontekście humanistycznie zorientowanych nauk o wychowaniu - Marian Nowak zauważył, że interdyscyplinarność (inaczej - międzydyscyplinarność), multidyscyplinarność (inaczej - wielodyscyplinarność) i transdyscyplinarność to stosunkowo młode pojęcia i zjawiska w dyskursie naukowym i praktyce badawczej. W wielu dziedzinach naukowych są one już utrwalone - zwłaszcza w humanistyce - a w innych dopiero się wyłaniają jako istotne kategorie określające różne modele współpracy między poszczególnymi dyscyplinami (na przykład w naukach społecznych). Przy tym interdyscyplinarność - zdaniem autora - jest zasadniczo odmienna od wielo- i interdyscyplinarności (Nowak 2012 249-250).
} 
kacja), znajdują się w fazie wewnętrznej rekompozycji i transformacji swojej roli społecznej. Wobec tego dążą do organizowania się nie tylko jako pola praktyki, które mogą być wzbogacane przez podejścia dyscyplinarne wyznaczające przedmiot badań, ale także do organizowania się w obrębie pola badawczego. Transformacji tej towarzyszy wiele orientacji epistemologicznych, teoretycznych i metodologicznych, które wymagają sprecyzowania. Przyjmuje się hipotezę wyjściową, że rozwój pól badawczych odpowiada polom praktyki. Ich analiza wymaga posłużenia się aparatem pojęciowym, który mógłby precyzyjnie połączyć konstruowanie aktywności z kształtowaniem podmiotów indywidualnych i zbiorowych (Barbier 2015).

Koncepcja analizy transwersalnej aktywności (por. Barbier 2015, 2016a) pozwala orientować problematykę w kierunku przestrzeni aktywności, ich konfiguracji i transformacji zachodzących w różnych przypadkach/sytuacjach edukacyjnych i społecznych. Transformacje te zachodzą stale i przypuszczalnie powstają wraz z innymi składnikami aktywności podmiotów działających. Warto w tym miejscu poczynić uwagę, co do cechy charakterystycznej przestrzeni edukacyjnej, którą stanowi bycie pomiędzy. 0 ile procesy edukacyjne można rozpatrywać z punktu widzenia zaangażowanych w nie podmiotów i ich biograficznego uwikłania, o tyle przestrzeń zawsze ma charakter „inter”, „na styku”, „na pograniczu”, „pomiędzy”. Sprzyja to - a jednocześnie czyni utrudnienie - w analizie konfiguracji i transformacji zachodzących w przestrzeniach aktywności.

Autor Leksykonu analizy aktywności, Barbier, twierdzi, że można mówić o antropologii praktyki, a przede wszystkim o antropologii praktyk profesjonalnych, co oznacza, że szerokiemu zakresowi pól praktyki odpowiada wspólna dla różnych pól badawczych struktura konceptualna (Barbier 2016a: 16).

\section{Podmiotowa aktywność w procesie rozwoju}

To, że dzieje się chociaż cokolwiek - może być jedyną szansą zaistnienia człowieka, który będąc istotą świadomą siebie i wrażliwą, bytuje na statusie człowieka podmiotu (Obuchowski 1985: 73).

Idea aktywności własnej podmiotu uczestniczącego w swoim rozwoju wyrosła z dostrzeżenia wielowymiarowej, systemowej organizacji świata, której człowiek jest częścią, co spowodowało przyjęcie podejścia dynamicznego w analizie ludzkiego zachowania i rozwoju (Trempała 2000, 2011; Pietrasiński 1987; Obuchowski 1998). Podmiotowa aktywność ma status podstawowego i najważniejszego wyznacznika rozwoju. Progresywny charakter aktywności człowieka polega na tym, że w ciągu życia poszerzają się dziedziny jego działania, usprawniają wykonywane przez niego czynności, przy czym zmianie ulega ich zasób, formy i rodzaje, w sposób zapewniający optymalną regulację stosunków z otaczającym światem (Przetacznik-Gierowska 1973: 181). 
Pytanie o podmiotowy czy przedmiotowy charakter człowieka sugeruje, że jest to sprawa wewnętrznej, czy zewnętrznej regulacji jego aktywności. Jeśli zachowanie się człowieka pozostaje pod dominującym wpływem czynników zewnętrznych, wtedy możemy go traktować jako przedmiot, jeżeli zaś przewagę mają czynniki wewnętrzne, wtedy możemy mówić, że człowiek jest podmiotem własnego zachowania się (Tomaszewski 1977: 60).

Twórca społeczno-poznawczej teorii uczenia się, Albert Bandura, scharakteryzował cztery rdzenne właściwości aktywności człowieka jako intencjonalność, przewidywanie, samoregulację i autorefleksyjność (Bandura 2001). Z punktu widzenia przedmiotu opracowania - analizy transformacji - warto zwrócić uwagę, iż rozwój definiowany jest jako ciąg zmian wynikających z organizowania się struktur doświadczenia (strukturacji) i ich przekształcania (restrukturacji). (Re)strukturacja doświadczenia jest koniecznością wymuszaną przez nabywanie przez podmiot doświadczeń, a zarazem warunkiem dostosowania jego dalszej aktywności do warunków środowiska zewnętrznego.

Rozwój nie jest monolitycznym procesem progresji i wzrostu, lecz zmiennym, wielokierunkowym oraz interakcyjnym systemem zysków i strat w zdolnościach adaptacyjnych człowieka. Od początku życia do jego końca każdemu wzrostowi towarzyszy spadek w tej samej lub innej dziedzinie funkcjonowania - i odwrotnie (Trempała 2000: 277).

Zgromadzone doświadczenia, po ich opracowaniu poznawczym, afektywnym i ewaluatywnym przyczyniają się do zmian konstrukcyjnych i funkcjonalnych. Doświadczenia kumulują się i organizują w struktury, które są spójne wewnętrznie, samosterowne i zdolne do rozwoju (Tyszkowa 1988).

\section{Heurystyka: Analiza aktywności jest aktywnością}

Przedmiotem analizy aktywności jest pojęcie działania definiowane jako to, co w odczuciu podmiotu konstytuuje znaczącą jedność jego aktywności. Tak formułowany przedmiot analizy $\mathrm{z}$ trudnością pomija problem tego, co stanowi o jego charakterze niepowtarzalnym i jednostkowym (Barbier 2016a: 18). Analiza aktywności jest dodatkowym elementem procesu. Istotne jest uznanie, że sam przebieg analizy jest aktywnością. Intencją analizy aktywności jest tworzenie wiedzy, które odbywa się w wymiarze historycznym i społecznym, w sposób procesualny i konstruktywistyczny. Stanowi ona jedynie pewien sposób aktywności ludzkiej i nie ma żadnego szczególnego statusu. Poza tym, że jej przedmiotem i celem jest poznanie innych aktywności ludzkich. Zasługuje na refleksję epistemologiczną dokonywaną z pewnego oddalenia (tamże: 19). Charakterystyczną cechą zarówno aktywności, 
jak i transformacji jest ich złożoność, powiązanie i równoległość występowania. Ich natura może być analizowana zarówno w kontekście widocznych modyfikacji aktywności, jak i w odniesieniu do możliwych antycypacji zdarzeń w polu praktyki. Przy organizowaniu przebiegów czynności, a także jego analizy jest ważna wiedza o okolicznościach działania, aktualnych i/lub potencjalnych.

Proces składa się z następujących faz: opracowanie projektu, czyli przedstawienie antycypowanej realizacji celu, stworzenie programu, ułożenie kolejnych etapów działania (jednostek czynności, operacji, ruchów itp.), wreszcie - podjęcie decyzji o działaniu. Te kolejne fazy tworzą sekwencję działań polegającą na tym, że każdy kolejny krok jest realizacją możliwości stworzonej przez krok poprzedni i sam z kolei stwarza możliwość realizacji kroku następnego (Tomaszewski 1998: 56-59).

Ta okoliczność wydaje się być istotna z punktu widzenia ujmowania aktywności jako „transformację transformacji” (Durand 2017; Marynowicz-Hetka 2018: 12). Tak rozumiana aktywność stanowi splot aktywności/transformacji obejmujących trzy wymiary - teraźniejszy, przeszły i przyszły oraz obecne w niej potencjały, które są aktualne, możliwe i domniemane (wirtualne)/wyobrażone. Namysł nad procesami transformacji, czy jak to chce Jean-Marie Barbier „myślenie o transformacjach”, zachodzi w różnych przestrzeniach. Są nimi: przestrzeń mentalna, którą uruchamiamy wówczas, gdy myślimy o (procesie, przebiegu) aktywności swojej lub drugiego, oraz przestrzeń wyobrażeniowa, gdy obmyślamy aktywność, i przestrzeń dyskursywna, gdy komunikujemy o podjęciu (przebiegu) aktywności. Analiza aktywności obejmuje liczne związki zachodzące pomiędzy tymi przestrzeniami (Marynowicz-Hetka 2018: 19).

\section{Doświadczenie jako przestrzeń transformacji i synergii}

Coś staje się przeżyciem, gdy nie tylko zostało przeżyte, lecz fakt przeżycia tego czegoś zostawił po sobie jakiś szczególny ślad, który treści przeżycia nadaje trwałe znaczenie (Gadamer 2007: 105).

Indywidualne i społeczne doświadczenie człowiek organizuje i interpretuje kompetentnie i twórczo (Maslow 1982; Kozielecki 1987; Obuchowski 1985; Gałdowa 2000). Nadaje im znaczenie, uruchamiając proces wartościowania (Trzebiński 2002; Straś-Romanowska 2002). Proces ten polega na selekcjonowaniu, interpretowaniu i porządkowaniu doświadczeń w pewną całość, których organizację wyznaczają motywy umacniania siebie i kontaktu z innymi (Trzebińska 1998). Proces wartościowania możliwy jest dzięki autorefleksji nad osobistym doświadczeniem z przeszłości, teraźniejszości i przyszłości (Obuchowski 1998). System znaczeń osobistych wyznacza interpretację nowych doświadczeń i przyczynia się 
do integrowania ich w spójną całość - co można traktować jak transformację. System znaczeń osobistych - reprezentacja najważniejszych celów jednostki i sposobów osiągania - ukierunkowuje codzienną aktywności oraz decyzje podejmowane przez podmiot (por. Trzebiński 2002). W tym znaczeniu zarówno aktywność, jak i transformacja jest powiązana i równoległa. Może być analizowana zarówno w kontekście nowych aktywności, jak i w odniesieniu do możliwych antycypacji zdarzeń. Pojęcie synergii oznacza współdziałanie, kooperację czynników skuteczniejszą niż suma ich oddzielnych działań (Kopaliński 1999: 484). Efekt synergii służy podkreśleniu wzmacniającego wymiaru rezultatów współpracy, współdziałania i współtworzenia.

\section{Życie: spiralny splot aktywności i procesy emergencji² świata}

W świetle tej koncepcji również życie definiuje się jako spiralny splot aktywności (Barbier 2016a; Marynowicz-Hetka 2018)). Stanowi proces, w którym i dzięki któremu realizowana jest aktywność jednostki i jej trwanie. Mechanizmy zachodzące $\mathrm{w}$ tym procesie charakteryzuje spiralne powiązanie. Jest to aktywność wielokrotnie złożona, podlegająca permanentnym transformacjom. Przykładem takiej aktywności jest (auto)biografia stanowiąca wytwór „interpretacyjnej, rozumiejącej, wyrażonej i utrwalonej w symbolach aktywności indywidualnego podmiotu. Konstruowanie biografii stanowi intencjonalne przekształcanie zbioru zdarzeń w wysoce znaczącą i ustrukturowaną całość" (Giza 1991: 99). Biografia jest zatem procesem konstruowania życia, jest refleksją nad nim oraz narzędziem jego zmiany i zmiany świata - konstruktywizmu (tamże: 102).

Warto jest zwrócić uwagę na organizację konstrukcji sensu wokół aktywności, w jakie podmioty są zaangażowane. Sens może być zdefiniowany jako skojarzenie dokonywane przez sam podmiot między reprezentacjami pochodzącymi z bieżącej aktywności i innymi reprezentacjami, które pojawiły się w trakcie jego drogi życiowej, Konstrukcje sensu są konstrukcjami mentalnymi, co wyjaśnia ich wyjątkową mobilność i niedostępność; nieodłącznie związane z konstrukcjami dyskursywnymi, obecnymi w interakcjach z innym, są wspierane lub przekształcane przez te konstrukcje; nie są jedynie konstrukcjami mentalnymi, mają bowiem ścisły związek z afektami i dyspozycjami/skłonnościami podmiotu do angażowania się w aktywności. Zatem kultury działania mogą być zdefiniowane jako sposoby organizujące aktywności konstruowania sensu (Barbier 2016b: 22-23).

Działalność/aktywność definiujemy - jak mówi Jean-Marie Barbier - jako zespół procesów transformacji świata fizycznego, mentalnego, społecz-

\footnotetext{
2 Emergentyzm to teoria głosząca, że „świat podlega nieustannemu rozwojowi, podczas którego powstają nagle, wciąż nowe wyższe jakości" (Słownik języka polskiego... 1988: 541). Emergencja (łac. Emergo - wynurzam się) - ,jako powstawanie nowych zjawisk w wyniku oddziaływania między prostymi elementami struktury" (Boudon 2008: 8).
} 
nego (często i wszystkich trzech razem), w które zaangażowany jest podmiot pozostający $w$ relacjach ze swoim otoczeniem, i jednocześnie $w$ transformacje samego podmiotu. Działalnością/aktywnością jest to, co podmiot robi w świecie i to, co się w nim samym dokonuje podczas tej aktywności Wszystkie aktywności (nawet te, które napotykają na trudności, czy te najbardziej tłumione) pozostawiają ślady w nas samych. Następnie te ślady odzwierciedlają się w kolejnych podejmowanych aktywnościach (Barbier 2015: 66).

\section{Twórczościowa (re)organizacja doświadczenia}

Twórczość to zbiór określonych wytworów lub proces stwarzania, wytwarzania, przetwarzania i odtwarzania (naśladowanie, rekonstruowanie, interpretowanie, tworzenie) albo też jest to dyspozycja lub właściwość podmiotowa, nadawanie istnienia $\mathrm{w}$ świadomym procesie (Stróżewski 1983: 16).

Twórczość można scharakteryzować jako aktywność ${ }^{3}$ prowadzącą do pojawienia się osiągnięć stanowiących podstawę dalszych zmian. Twórczość ma heterogeniczny, zróżnicowany charakter i nie ma twórczości $\mathrm{w}$ ogóle, istnieje natomiast wiele kategorii twórczego zachowania człowieka, wiele rodzajów twórczości i wiele różnych form twórczego zaangażowania człowieka. „Jedność w różnorodności” - to formuła, która najlepiej oddaje istotę współzależności między jednolitymi i zróżnicowanymi aspektami twórczej aktywności człowieka (Schulz 1990: 246). Twórczość ma naturę antynomiczną i dialektyczną. Opozycje istniejące w ramach procesu twórczego są ujmowane jako: elementy twórczej sytuacji dialogowej, do których należą twórca-dzieło, twórca-odbiorca, twórca-twórca; czynniki wyznaczające ontologiczne uwarunkowania procesu twórczego, np. determinizm-indeterminizm, konieczność-wolność, dynamiczność-statyczność; podstawy podmiotowe, np. poddanie-dominacja, sposoby czynnych zachowań podmiotowych, np. spontaniczność-kontrola, stwarzanie-odkrywanie; idee kierownicze, np. nowatorstwo-perfekcjonizm, estetyzm-antyestetyzm; najważniejsze odmiany jakości, ujawniające się w czasie tworzenia, np. stare-nowe, oryginalne-wtórne (Stróżewski 1983: 65). Systemowe (interakcyjne, integracyjne) koncepcje traktują twórczość jako aktywność zdeterminowaną wieloma czynnikami (komponentami) wchodzącymi w interakcje (Szmidt 2004, 2009)4. W kontekście rozpatrywanej

\footnotetext{
3 Twórczość może być rozpatrywana w obrębie czterech kategorii: jako dzieło (wytwór), twórczość jako proces, twórczość jako zespół specyficznych cech osobowości bądź zespół zdolności i uzdolnień, twórczość jako zespół stymulatorów społecznych (społeczny klimat uwarunkowań twórczości) (Strzałecki 1969: 13-27).

${ }^{4}$ Ujęcie systemowe sprawia, że twórczości nie da się sprowadzić do jednego procesu czy też czynnika, zwłaszcza natury psychologicznej, ponieważ dopiero interakcyjne oddziaływanie poznania, emocji, osobowości i kontekstu społecznego może sprawić, że powstanie liczące się dzieło. Twórczości nie
} 
problematyki transformacji twórczość jest aktywnością wielokrotnie złożoną, podlegającą permanentnym transformacjom. Proces twórczy polega na interakcji założonego celu aktywności twórczej i kolejno tworzonych struktur próbnych: rozwiązań, idei, pomysłów. Może zacząć się od - określenia celu, ale również - od sformułowania pierwszej struktury próbnej. Dzięki procesowi twórczemu następuje - (re)organizacja dotychczasowego doświadczenia - pod wpływem nowych informacji bądź zmiany celu aktywności. Kreatywność jako zespół cech człowieka ujawnia się $\mathrm{w}$ wyniku podejmowania przez niego aktywności twórczej i przejawia się $\mathrm{w}$ formie obserwowalnego zachowania, polegającego na produkcji nowych i wartościowych wytworów - przy czym wytworem może być niekiedy samo zachowanie (Nęcka 2012: 20) ${ }^{5}$. Zgodnie z teorią inwestycyjną twórczość wymaga współdziałania sześciu powiązanych ze sobą czynników: zdolności intelektualnych (tu m.in. zdolność syntetyzowania i analizowania oraz zdolności praktyczne), wiedzy, stylu myślenia (szczególnie stylu legislacyjnego), cech osobowości (specyficznych dla twórczych osób, jak np. tolerancja dwuznaczności, odwaga do podejmowania rozsądnego ryzyka), motywacji, środowiska (wspierającego otoczenia społecznego) (Sternberg, Lubart 1999).

\section{Proces twórczy jako transformacja (transformacji)}

Spontaniczny charakter twórczości nie poddaje się prostym zabiegom algorytmizacji i mechanizacji. Heurystyczność procesu twórczego w dużej mierze decyduje o jego nieciągłości, intuicyjności i pewnej tajemniczości (Kozielecki 1992: 202).

W procesie przekształceń perspektywą analizy jest rozpatrywanie dynamik obecnych w danej sytuacji przed pojawieniem się samej aktywności czy działania (Barbier 2015: 68). Przy rozpatrywaniu transformacji czynności konstytuujących aktywności promowane jest podejście dynamiczne. Kwestia ta zasługuje na szczególną uwagę. Zakłada się, że aktywność nie jest jedynie jednorazowym konstruowaniem, jest rekonstruowaniem, a nawet ciągłym/nieprzerwanym rekonstruowaniem. Jest to kwestia najtrudniejsza zarówno pod względem epistemologicznym, jak i metodologicznym w badaniach, których przedmiotem są aktywności. Zatem proces przekształceń należałoby rozpatrywać nie tyle w kategoriach etapów, ile $\underline{\mathrm{w}}$ kategoriach funkcji obecnych $\mathrm{w}$ analizowanej aktywności. Analiza działania

można też rozpatrywać w oderwaniu od czynników makrospołecznych: kulturowych, politycznych i ekonomicznych (Nęcka 2012: 173).

5 Twórczość w odniesieniu do dzieci, choć nie prowadzi do powstania dzieł o wyjątkowym i trwałym charakterze, stanowi jednak tę formę jego działalności, która pozwala mu przekształcać rzeczywistość w jej różnych zakresach - poznawania, doświadczania, przeżywania. Każde rozpoznanie jest doświadczeniem rosnącego oswojenia, a wszelkie doświadczenia świata są w końcu formami naszego radzenia sobie z nim (Gadamer 2000: 151). 
odniesiona do dziedziny kształcenia ${ }^{6}$ prowadzi do stopniowego rozpatrywania konstruowania trzech funkcji związanych z kontekstem pojawienia się propozycji wykonania dzieła, z projektowaniem/architekturą pomysłu i z wykonaniem (realizacją).

W analizie transformacji czynności obie perspektywy - dynamiki oraz funkcji przekształceń - są obecne w procesie twórczym (tworzenia). Mechanizm twórczości może być wyjaśniony, gdy uwzględni się fakt, że aktywność twórcza jest z natury swojej celowa, bo polega na dążeniu do stanów wyróżnionych, którym można przypisać cechy nowości i wartości.

Każda czynność jest analizą sytuacji poprzedzającej, a dopiero później następuje sytuacja (czynność) wykonawcza. Jeżeli każda kolejna operacja wykazuje zgodność z założonym celem, to wówczas czynność jest akceptowana. Czyli, że cel i etapy wykonania wykazują rozbieżności, które należy stopniowo niwelować, aż do zbieżności wykonania z celem (Nęcka 1994: 23).

Na początku drogi zwanej procesem twórczym staje wyobraźnia, na jej końcu jest konkretny wytwór w formie zobiektywizowanej. Między narodzinami pomysłu w wyobraźni a jego zmaterializowaniem jest długa droga, którą w całości nazywa się procesem twórczym (Górniewicz, Rubacha 1993). Szerzej wyobraźnię można określić jako zdolność do przekraczania granic własnego doświadczenia (Wojnar 1982). Jest to pewna forma transgresji ${ }^{7}$ polegającej na wychodzeniu poza to, czym jednostka jest i co posiada, a jej istotą staje się przełamywanie dotychczasowych granic osiągnięć i tworzenie lub asymilacja nowych wartości: „Człowiek staje się tym, czym może być, a czym jeszcze nie jest” (Kozielecki 1987: 13)ํ․ Podstawę myślenia stanowi zdolność do symbolicznego reprezentowania rzeczywistości: przedmiotów, ludzi, doświadczeń czy zdarzeń. Cechą charakterystyczną wyobraźni twórczej jest dynamiczność obrazów umysłowych, która związana jest z ciągłym

\footnotetext{
${ }^{6}$ Kwestią dyskusyjną jest argumentacja, którą wysuwa Jean-Marie Barbier, iż w sytuacjach nauczania mniej ważne są same aktywności, najważniejsze zaś wydają się kompetencje. Wyjaśnia to włączanie wszelkich form ćwiczeń i treningów do programów nauczania - jak argumentuje autor - być może dlatego, że „tak jest szybciej”. Podmioty działające w obszarze edukacji przyjmują raczej, że działalność (aktywność) prowadzi do transformacji podmiotów, które są w nią zaangażowane. Wedle tej argumentacji - efektem uczenia nie jest już pogłębione poznanie teorii - lecz jej praktykowanie (Barbier 2015: 66).

7 Zagadnienie transgresyjnej aktywności człowieka zostało omówione w następujących opracowaniach autorskich (por. Wróblewska 2018, 2019).

${ }^{8}$ Zachowania transgresyjne występują jako działania ekspansywne, polegające na przełamywaniu dotychczasowych granic, oraz jako działania twórcze, których celem jest poszerzanie granic ludzkiego poznania. Myślenie i działania twórcze są najbardziej specyficznymi rodzajami transgresji psychologicznych i historycznych. Cele transgresyjne zakładają zastosowanie innowacyjnych zmian. Dostrzeżenie potrzeby wprowadzenia zmiany i odczuwane niezadowolenie może motywować do poszukiwania sposobu redukcji spostrzeganej rozbieżności. Znalezienie właściwego rozwiązania - rodzaju, formy i zakresu zmiany, jest uzależnione od posiadanych uzdolnień i cech osobowości ujmowanych jako postawa twórcza i wyznacznik poziomu kreatywności jednostki.
} 
przekształcaniem obrazów mentalnych w jakościowo odmienne wyobrażenia. Materiałem dla wyobraźni twórczej są umysłowe obrazy, transformowane dzięki myśleniu metaforycznemu i kojarzeniu przez analogię (Limont 1996). Cechy typowe dla procesu twórczego myślenia i rozwiązywania problemów: ruchliwość, czyli spontaniczne zmienianie kierunku, syntezowanie, łączenie idei i faktów, nawet bardzo od siebie odległych i pierwotnie niespójnych, w nową i sensowną całość, aktywny stosunek do zadania lub tworzywa, samodzielne przełamywanie bloku psychicznego oraz działanie w sytuacji niedoboru środków (Nęcka 1994: 21). Proces twórczy odbywa się poprzez operacje umysłowe (kojarzenie, abstrahowanie, metaforyzowanie) pozostające pod kontrolą strategii heurystycznych (Nęcka 1995). Szczególne znaczenie w procesie twórczym ma zdolność dostrzegania, definiowania i redefiniowania problemów oraz płynność i giętkość myślenia. Cechami zadań będącymi warunkiem tworzenia są dywergencyjność ${ }^{9}$, heurystyczność, różnorodność i komplementarność oraz autentyczność. Rozpatrując dwa typy strategii rozwiązywania problemów: algorytmiczną i heurystyczną - reguły heurystyczne odgrywają szczególną rolę w czasie rozwiązywania zadań złożonych, niekonwencjonalnych i twórczych.

Heurystyki to reguły, instrukcje bądź intuicje, które są mniej określone niż algorytmy; w przeciwieństwie do tamtych są zawodne, nigdy nie ma gwarancji, że za pomocą heurystyk - nawet tych najlepszych - człowiek osiągnie rozwiązanie zadania. Mają one jednak tę zaletę, że drastycznie redukują trudność zadania i niezbędny do jego rozwiązania wysiłek poznawczy (Kozielecki 1992: 190).

\section{Ekspresja emocjonalna ${ }^{10} \mathbf{w}$ działaniach twórczych}

Emocje są pierwszym językiem nas wszystkich. Emocja spowodowana jest zazwyczaj przez świadome lub nieświadome wartościowanie przez podmiot jakiegoś zdarzenia jako istotnego dla jakiejś ważnej dla niego spra-

\footnotetext{
9 Dywergencyjność wymaga płynności, giętkości i oryginalności myślenia. Płynność rozumiana jako łatwość generowania nowych pomysłów jest elementem niezbędnym do dostrzegania konieczności zmian, giętkość wskazuje na gotowość do modyfikowania kierunku aktywności intelektualnej, a oryginalność jest umiejętnością kształtowania nietypowych związków pomiędzy różnymi elementami (Guilford 1978).

${ }^{10}$ Ekspresja stanowi uzewnętrznienie doświadczenia indywidualnego. Szczególnie istotne jest ujęcie ekspresji emocjonalnej, która może przybierać bardzo różnorodną formę. U podłoża ekspresji leży mechanizm projekcji. Projekcja jest w pewnym sensie ekspresją, procesem, który stanowi nieodłączny atrybut egzystencji człowieka. Z jednej strony występuje zawsze w stanach afektywnych i jest formą przystosowania, jest więc zjawiskiem bardzo powszechnym, z drugiej natomiast wydaje się być złożona, łącząc w sobie zarówno elementy emocjonalne, jak i poznawcze. Ponadto stanowi zarówno przejaw różnorodnych mechanizmów obronnych, jak i mechanizmów kreacyjnych. Analiza materiału projekcyjnego zebranego $\mathrm{w}$ badaniach własnych potwierdziła zaangażowanie $\mathrm{w}$ mechanizm projekcji procesów poznawczych - percepcji, wyobraźni, pamięci - oraz sfery podmiotowej, potrzeb, stanów emocjonalnych i motywacji (Wróblewska 2015: 218-280).
} 
wy. Rdzeniem emocji jest gotowość do działania i podsuwanie planów (Oatley, Jenkins 2003: 53).

W podejściu dynamicznym - w odniesieniu do procesu przekształceń - perspektywą analizy jest uznanie statusu pojęcia emocji będących jednocześnie motorem aktywności nadającym rytm działaniom, jak też pośrednikiem między zjawiskami mentalnymi, afektywnymi i poznawczymi (Babier 2015: 68).

Powstawanie emocji jest rezultatem oceny interakcji jako znaczącej, ważnej pod jakimś względem dla podmiotu (Jarymowicz 2001). Ta interakcja przebiegająca między doświadczającym podmiotem a różnymi aspektami rzeczywistości poprzez styl, klimat, właściwości posiada swoją jakość. Ponadto, interakcja zawsze przebiega $\mathrm{w}$ danym kontekście, w danym miejscu i czasie. Kontekst interakcji tworzy także sam podmiot wraz ze swoimi dyspozycjami i doświadczeniem - co jest istotne dla zrozumienia jakości interakcji. Dokładnie na tę interakcję wraz z jej właściwościami podmiot odpowiada (jej doświadcza), percypuje sytuację interakcyjną, odnosi ją do siebie, porównuje z wcześniejszymi sytuacjami. Sposób czy forma odpowiedzi na daną interakcję jest emocją. Interakcja i przyjęte określenie „odpowiedź” (a nie reakcja) wyraźnie akcentuje fakt, że $\underline{w}$ tworzeniu emocji człowiek jest kimś aktywnym, jest podmiotem i sprawcą. Można zatem powiedzieć, że aktywność i sprawstwo w tworzeniu emocji sprowadza się do intencjonalnego działania na rzecz odkrywania coraz to nowych i innych obiektów interakcji (Gasiul 2001: 27). Emocje człowieka charakteryzuje społeczny charakter, intencjonalność oraz poznawcza treść (Jarymowicz 2001, 2009). Emocje pełnią rolę moderatora procesu twórczego. Funkcja heurystyczna emocji w procesie twórczym polega na wzbudzaniu procesów poznawczych sprzyjających wytwarzaniu giętkości poznawczej, eksploracji, odległych skojarzeń. Pośrednio wpływa na wyznaczanie kierunków aktywności. Funkcja ta realizuje się w warunkach emocjonalnych sprzyjających uzyskiwaniu twórczych rezultatów ${ }^{11}$. Funkcja ewaluatywna polega na wyznaczaniu kierunku eksploracji, podejmowania decyzji dotyczących działania i oceniania wyników aktywności. Funkcja energetyzująca polega na mobilizacji energii, czyli podwyższaniu aktywacji. Funkcja motywacyina realizowana jest za pośrednictwem emocji poznawczych, związanych z Ja, jest powiązana z funkcją ewaluatywną i zależy od kontekstu motywacyjnego aktywności (Tokarz 2005).

\footnotetext{
${ }^{11}$ Emocje wpływające na proces twórczy: kierujące tym procesem (również stany afektywne samego podmiotu) oraz emocje mające pochodzenie zewnętrzne względem twórcy. Czynniki emocjonalne mogą proces twórczy uaktywnić, wspomóc, podtrzymać, ukierunkować bądź też zakłócić lub nawet zablokować (Nęcka 1995: 77).
} 


\section{Konkluzja}

Sensotwórcza aktywność człowieka, podobnie jak rozwój, stanowi proces przebiegający dynamicznie według ciągłego mechanizmu: adaptacji - zróżnicowania - kreacji. Perspektywa rozwoju aktywności człowieka w ciągu życia pozwala spojrzeć na twórczość jak na szerokie spektrum zachowań adaptacyjnych, które można sprowadzić do rezultatu: od przystosowania się do świata - do przystosowania świata do siebie. Paradygmat interakcji zakłada, że człowiek może funkcjonować bardziej adaptacyjnie (przystosowawczo) lub bardziej innowacyjnie (twórczo, prokreatywnie) (Popek 2001).

Obszar, jakim jest proces tworzenia, w perspektywie transwersalnej stanowi heurystyczny wymiar poszukiwań. W tym kontekście twórczość jest aktywnością wielokrotnie złożoną, podlegającą permanentnym transformacjom. Wykracza poza jeden proces, a stanowi interakcyjne oddziaływanie poznania, emocji, osobowości i kontekstu społecznego. W procesie twórczym (tworzenia) obecne są obie perspektywy - dynamiki oraz funkcji przekształceń. Zarówno aktywność, jak i transformacja mogą być analizowane w kontekście nowych aktywności, jak też w odniesieniu do możliwych antycypacji zdarzeń. Podobnie jak w procesie przekształceń, również w twórczości perspektywą analizy jest uznanie statusu pojęcia emocji będących pośrednikiem między zjawiskami poznawczymi, afektywnymi i mentalnymi. Doświadczenie indywidualne stanowi materiał rozwoju, w którym dokonuje się proces transformacji i twórczościowej (re)strukturyzacji. Transformacje czy „transformacje transformacji”, w których są przekraczane granice doświadczenia, wykazują podobieństwo do działań transgresyjnych. Zatem „myślenie o transformacjach" może zachodzić w różnych przestrzeniach, natomiast dziedzina aktywności twórczej jest w tym zakresie szczególną. Ukazuje wieloaspektową/wielowymiarową płaszczyznę interakcji, transformacji, modyfikacji, jak również interpretacji znaczeń i dyskursów. W płaszczyźnie tej dokonuje się synergia (współtworzenie).

\section{Bibliografia}

Barbier J.-M. (2015) Nowe wyzwania dla badań w naukach o wychowaniu: perspektywa działania/aktywności, tłum. Grażyna Karbowska, „Nauki o Wychowaniu. Studia Interdyscyplinarne", nr 1.

Barbier J.-M. (2016a) Leksykon analizy aktywności. Konceptualizacje zwyczajowych pojęć, tłum. i oprac. E. Marynowicz-Hetka, Łódź, Wydawnictwo Uniwersytetu Łódzkiego.

Barbier J.-M. (2016b) Kultury działania i podzielane sposoby organizacji konstrukcji sensu, tłum. Grażyna Karbowska "Nauki o Wychowaniu. Studia Interdyscyplinarne”, 2 (3), s. 14-46, https://doi.org/10.18778/2450-4491.03.02 
Bandura A. (2001) Teoria społecznego uczenia się, tłum. J. Kowalczewska, J. Radzicki, Warszawa, Wydawnictwo Naukowe PWN.

Boudon R. (2008) Efekt odwrócenia, tłum. A. Karpowicz Warszawa, Oficyna Naukowa.

Dudzikowa M. (2012) Sytuacja problematyczna interdyscyplinarności w naukach społecznych i humanistycznych z kryzysem $w$ tle $\mathrm{w}$ : Interdyscyplinarnie o interdyscyplinarności. Między ideq a praktyka, A. Chmielewski, M. Dudzikowa, A. Grobler (red.), Kraków, Oficyna Wydawnicza „Impuls”, s. 15-38.

Durand M. (2017) L'activité en transformation w: Encyclopédie d'analyse des activités, J.-M. Barbier, M. Durand (red.), Paris, Presses Universitaires de France, s. 33-55.

Gadamer H.G. (2007) Prawda i metoda, Warszawa, Wydawnictwo Naukowe PWN.

Gałdowa A. (2000) Powszechność i wyjątek, Kraków, Wydawnictwo Uniwersytetu Jagiellońskiego.

Gasiul H. (2001) W poszukiwaniu podstaw rozwoju „ja” emocjonalnego, Warszawa, Wydawnictwo Akademickie „Żak”.

Guilford J. P. (1978) Natura inteligencji człowieka, tłum. B. Czarniawska, W. Kozłowski, J. Radzicki, Warszawa, Państwowe Wydawnictwo Naukowe.

Giza A. (1991) Życie jako opowieść. Analiza materiałów autobiograficznych w perspektywie socjologii wiedzy, Wrocław-Warszawa-Kraków, Zakład Narodowy Ossolińskich Wydawnictwo PAN.

Górniewicz J., Rubacha K. (1993) Samorealizacja a uzdolnienia twórcze młodzieży. Przegląd koncepcji i studium empiryczne, Toruń, Wydawnictwo Uniwersytetu Mikołaja Kopernika.

Jarymowicz M. (2009) Psychologiczne podstawy podmiotowości. Szkice teoretyczne, studia empiryczne, Warszawa, Wydawnictwo Naukowe PWN.

Jarymowicz M. (red.) (2001) Pomiędzy afektem a intelektem: poszukiwania empiryczne, Warszawa, Wydawnictwo Instytutu Psychologii PAN.

Kopaliński W. (1999) Słownik wyrazów obcych i zwrotów obcojęzycznych z almanachem, Warszawa, Muza SA.

Kozielecki J. (1987) Koncepcja transgresyjna człowieka. Analiza psychologiczna, Warszawa, Państwowe Wydawnictwo Naukowe.

Kozielecki J. (1992) Myślenie i rozwiązywanie problemów w: Psychologia ogólna, T. Tomaszewski (red.), Warszawa, Państwowe Wydawnictwo Naukowe, s. 91-188. 
Limont W. (1996) Analiza wybranych mechanizmów wyobraźni twórczej, Toruń, Wydawnictwo Uniwersytetu Mikołaja Kopernika.

Marynowicz-Hetka E. (2008) Interdyscyplinarność czy transwersalność - możliwe konfiguracje podejść do analizy pola praktyki, „Rocznik Pedagogiczny”, t. 31, s. 55-65.

Marynowicz-Hetka E. (2018) Myśląc o życiu duchowym/mentalnym w kontekście aktywności: transformacje bezszelestne versus modyfikacje, „Studia z Teorii Wychowania", nr 1 (22), s. 9-24.

Maslow A. H. (1982) Postawa twórcza, „Literatura na Świecie”, nr 3/4, s. 47-53.

Nęcka E. (1994) TRoP. Twórcze rozwiązywanie problemów, Kraków, Oficyna Wydawnicza „Impuls”.

Nęcka E. (1995) Inteligencja i procesy poznawcze, Kraków, Oficyna Wydawnicza „Impuls".

Nęcka, E. (2012) Psychologia twórczości, Sopot, Gdańskie Wydawnictwo Psychologiczne.

Nowak M. (2012) Pedagogiczny profil nauk o wychowaniu. Studium z odniesieniami do pedagogiki pielęgniarstwa, Lublin, Wydawnictwo KUL.

Oatley K. O., Jenkins J. M. (2003) Zrozumieć emocje, tłum. M. Guzowska, Warszawa, Wydawnictwo Naukowe PWN.

Obuchowski K. (1985) Adaptacja twórcza, Warszawa, Książka i Wiedza.

Obuchowski K. (1998) Człowiek intencjonalny, Warszawa, Wydawnictwo Naukowe PWN.

Pietrasiński Z. (1987) Człowiek formowany jako podmiot rozwoju, „Psychologia Wychowawcza", nr 3, s. 249-271.

Popek S. (2001) Człowiek jako jednostka twórcza, Lublin, Wydawnictwo UMCS.

Przetacznik-Gierowska M. (1973) Podstawy rozwoju psychicznego dzieci i młodzieży, Warszawa, Państwowe Zakłady Wydawnictw Szkolnych.

Przetacznik-Gierowska M. (1996) Zasady i prawidłowości psychicznego rozwoju człowieka w: Psychologia rozwoju człowieka, t. 1: Zagadnienia ogólne, M. Przetacznik-Gierowska, M. Tyszkowa (red.), Warszawa, PWN.

Schulz R. (1990) Twórczość - społeczne aspekty zjawiska, Warszawa, Państwowe Wydawnictwo Naukowe. 
Słownik języka polskiego (1988), t. 1, Warszawa, Państwowe Wydawnictwo Naukowe.

Sternberg R. J., Lubart T. (1999) The concepts of creativity: prospects and paradigms w: Handbook of Creativity, R. J. Sternberg (red.), Cambridge, Cambridge University Press.

Straś-Romanowska M. (2002) Rozwój człowieka a rozwój osobowy, „Studia Psychologica", nr 3, s. 91-104.

Stróżewski W. (1983) Dialektyka twórczości, Kraków, Polskie Wydawnictwo Muzyczne.

Strzałecki A. (1969) Wybrane zagadnienia psychologii twórczości, Warszawa, Państwowe Wydawnictwo Naukowe.

Szmidt K. J. (2004) Systemowe teorie twórczości i ich pedagogiczne implikacje w: Twórczość w teorii i praktyce, S. Popek (red.), Lublin, Wydawnictwo UMCS.

Szmidt K. J. (2009) Metody pedagogicznych badań nad twórczościq̨: teoria i empiria, Łódź, Wydawnictwo Akademii Humanistyczno-Ekonomicznej.

Tokarz A. (2005) Dynamika procesu twórczego, Kraków, Wydawnictwo Uniwersytetu Jagiellońskiego.

Tomaszewski T. (1977) Człowiek jako podmiot i człowiek jako przedmiot w: Studia z psychologii emocji, motywacji i osobowości, J. Reykowski, O. W. Owczynnikowa, K. Obuchowski (red.), Wrocław, Wydawnictwo Ossolineum.

Tomaszewski T. (1998) Czynność w: Encyklopedia psychologii, W. Szewczuk (red.), Warszawa, Wydawnictwo Fundacja „Innowacja”, s. 56-59.

Trempała J. (2000) Modele rozwoju psychicznego. Czas i zmiana, Bydgoszcz, Wydawnictwo Uczelniane Akademii Bydgoskiej im. Kazimierza Wielkiego.

Trempała J. (2011) Mechanizmy zmiany rozwojowej w: Psychologia rozwoju człowieka: podręcznik akademicki, J. Trempała (red.), Warszawa, Wydawnictwo Naukowe PWN.

Trzebińska E. (1998) Dwa wizerunki własnej osoby: studia nad sposobami rozumienia siebie, Warszawa, Wydawnictwo Instytutu Psychologii.

Trzebiński J. (2002) (red.) Narracja jako sposób rozumienia świata, Gdańsk, Gdańskie Wydawnictwo Psychologiczne.

Tyszkowa M. (1988) Rozwój psychiczny jednostki jako proces strukturyzacji i restrukturyzacji doświadczenia w: Rozwój psychiczny człowiek w ciąu życia. Zagadnienia teoretyczne i metodologiczne, M. Tyszkowa (red.), Warszawa, Państwowe Wydawnictwo Naukowe, s. 44-79. 
Wojnar I. (1976) Teoria wychowania estetycznego, Warszawa, Państwowe Wydawnictwo Naukowe.

Wojnar I. (1982) Estetyczna samowiedza człowieka, Warszawa, Państwowe Wydawnictwo Naukowe.

Wróblewska M. (2015) Kompetencje twórcze a organizacja i interpretacja doświadczenia indywidualnego w: M. Wróblewska, Kompetencje twórcze w dorosłości, Białystok, Wydawnictwo Trans Humana, Białystok, s. 218-280.

Wróblewska M. (2018) Expanding the Boundaries of Self: Self-Realization, Trangression, and Creative Competence, „Rocznik Teologii Katolickiej”, vol. 2, s. 163-174, https://doi.org/10.15290/rtk.2018.17.2.12

Wróblewska M. (2019) Człowiek - Sprawca transgresyjny. Podejście badawcze w aspekcie twórczym i biograficznym w: Homo transgressivus w poszukiwaniu sensu istnienia. Od transgresji do transcendencji?, A. Ciążela, S. Jaronowska (red.), Warszawa, s. $155-177$.

Wróblewska M. (2020) Granice i transgresje (w) edukacji?, „Lubelski Rocznik Pedagogiczny", nr 3 (39), s. 203-215.

\section{Activity - Creativity - Emotions. Spaces of Transformation and Synergy}

\section{Summary}

The subject of the article is a reflection on the transformation processes taking place in a complex space of activity at the intersection of experience, cognition, creativity and emotions. The starting point for the considerations is the concept of the analysis of transversal activity - as Jean-Marie Barbier puts it - which allows an orientation of the issues towards the space of activity, their configuration and transformation taking place in various educational and social cases/situations (Barbier 2015, 2016). In terms of thinking about transformations, the field of creative activity is special. The study shows the structure of creative activities in order to use it to analyse a specific type of transformative behaviour. The creative process can be viewed as "transformation transformation" and synergy. The synergy effect serves to underline the empowering dimension of the results of cooperation, collaboration and co-creation. The area of the creative process, in the transversal perspective, is the heuristic dimension of the search. In this context, creativity is an activity that is many times interwoven, subject to permanent transformation. It goes beyond one process and is the interactive cooperation of cognition, emotions, personality and social context. In the creative process (creation), both perspectives are present - dynamics and the function of transformations. As in the process of transformation, also in creativity, the perspective of analysis is to recognize the status of the concept of emotions, which are an 
intermediary between cognitive, affective and mental phenomena. Transformations in which the boundaries of experience are crossed are similar to transgressive activities. They show a multifaceted/multidimensional plane of interaction, transformation, and modification as well as interpretation of meanings and discourses. Human creative activity, like development, is a dynamic process according to a continuous mechanism: adaptation - differentiation - creation.

\section{Activité - création - émotions. Espaces de transformation et de synergie}

\section{Résumé}

L'article traite des processus de transformation qui se déroulent dans un espace d'activités complexe à la jonction des expériences, de la cognition, de la création et des émotions. Le point de départ de la réflexion est le concept d'analyse transversale de l'activité - d'après Jean-Marie Barbier - qui permet d'orienter les questions vers les espaces d'activité, leurs configurations et transformations qui se produisent dans différents cas/situations éducatives et sociales (Barbier 2015, 2016). En ce qui concerne la réflexion sur les transformations, le domaine de l'activité créative est tout particulier. L'étude révèle la structure des activités créatives en vue de leur utilisation pour analyser un type spécifique de comportements transformateurs. Le processus créatif peut être considéré comme une "transformation de transformation " et de synergie. L'effet de synergie vise à renforcer la dimension des résultats de la coopération, de l'interaction et de la cocréation. L'espace du processus de la création, dans une perspective transversale, est la dimension heuristique de l'exploration.

Dans ce contexte, la création est une activité extrêmement complexe, sujette à des transformations permanentes. Elle va au-delà d'un seul processus et constitue un impact interactif de la cognition, des émotions, de la personnalité et du contexte social. Dans le processus créatif (de création), les deux perspectives sont présentes : la dynamique et la fonction de transformation. Dans l'analyse du processus il convient de reconnaître le statut des émotions qui servent d'intermédiaire entre les phénomènes cognitifs, affectifs et mentaux.

Les transformations qui dépassent les limites de l'expérience présentent une similitude avec les actions transgressives. Ils montrent un plan multiforme/multidimensionnel d'interaction, de transformation, de modification, ainsi que d'interprétation des significations et des discours. L'activité créative de l'homme comme son développement, est un processus dynamique se déroulant selon un mécanisme continu : adaptation - différenciation - création.

\section{Cytowanie}

Wróblewska H. M. (2021) Aktywność - twórczość - emocje. Przestrzenie transformacji i synergii, „Nauki o Wychowaniu. Studia Interdyscyplinarne” 2(13), 299-316, https://doi.org/10.18778/2450-4491-13.17 